\title{
In situ stable isotopic constraints on dolomitizing fluids for the hydrothermally-originated saddle dolomites at Keping, Tarim Basin
}

\author{
DONG ShaoFeng $^{1,2}$, CHEN DaiZhao $^{1 *}$, QING HaiRuo $^{3}$, JIANG MaoSheng $^{1} \&$ \\ ZHOU XiQiang ${ }^{1,2}$ \\ ${ }^{1}$ Key Laboratory of Petroleum Resources Research, Institute of Geology and Geophysics, Chinese Academy of Sciences, Beijing 100029, China;
${ }^{2}$ Graduate University of Chinese Academy of Sciences, Beijing 100049, China; \\ ${ }^{3}$ Department of Geology, University of Regina, Regina SK, S4SOA2, Canada
}

Received January 9, 2013; accepted February 26, 2013; published online April 10, 2013

\begin{abstract}
Detailed characterization of diagenetic fluid behaviour and evolution is commonly hindered by shortage of appropriate and economic methods to carry out in situ analysis in the tiny diagenetic mineral crystals. Using micromill sampling method, this study presents in situ stable isotopic data for the growth zones of saddle dolomite crystals in the hydrothermally-altered dolostones of Upper Cambrian (Furongian) at Keping, Tarim Basin, NW China. These data show minor and large variations in $\delta^{13} \mathrm{C}(-0.7 \%$ o to $-1.5 \%$ o VPDB) and $\delta^{18} \mathrm{O}(-8.3 \%$ o to $-13.8 \%$ o VPDB), respectively, from the cores to outer rims of the dolomite crystals and suggest that saddle dolomites precipitated from dolomitizing fluids with similar carbon sources but oscillatory temperatures during different formation stages. This scenario is confirmed by microthermometry of fluid inclusions within the growth zones of dolomite crystals. This study indicates that in situ isotope analysis could provide more detailed information related to the source and pathway of dolomitizing fluids, facilitating better characterization of dolomitizing fluids and processes.
\end{abstract}

Tarim Basin, Upper Cambrian, saddle dolomite, micromill sampling, in situ stable isotope analysis, fluid inclusion microthermometry, petrography

Citation: Dong S F, Chen D Z, Qing H R, et al. In situ stable isotopic constraints on dolomitizing fluids for the hydrothermally-originated saddle dolomites at Keping, Tarim Basin. Chin Sci Bull, 2013, 58: 2877-2882, doi: 10.1007/s11434-013-5801-7

Geochemical variations of diagenetic minerals are commonly considered as the robust proxies to trace the fluidrock interactions, sources and pathways of diagenetic fluids. Numerous researches had already successfully applied different geochemical approaches to determine the types and pathways of dolomitizing fluids during dolomitization [1-8]. However, such efforts are commonly hindered by shortage of appropriate and affordable methods to extract in situ compositional information indicative of primary dolomitizing fluids from the tiny diagenetic minerals. Therefore, single mineral crystals, even whole rock samples, are more often used for geochemical analysis; this would readily result in mixing of geochemical signatures from different formation stages, limiting exact assessment for the diage-

*Corresponding author (email: dzh-chen@mail.iggcas.ac.cn) netic fluid and its evolution.

In recent decades, numerous efforts have been made to develop reliable and affordable in situ isotope analysis methods with high spatial resolution. This greatly extends their applications in reconstruction of paleo-environment and paleofluid history [9-14]. Although laser ablation sampling can provide higher spatial resolution $(\sim 10$ 's $\mu \mathrm{m})$ for in situ stable isotopic analysis, the uncertainties induced by composition-dependent isotope fractionation during laser ablation limit the routine application of this technique for carbonate rocks $[9,11,14]$.

In order to better characterize the source and pathway of dolomitizing fluids, in situ stable isotope analysis, integrated with cathodoluminescence (CL) microscopy and microthermometry of fluid inclusions, were performed on the growth zones of saddle dolomite crystals from the hydro- 
thermally-altered dolostones in the Lower Qiulitag Group of Upper Cambrian (or Furongian) well cropped out at Keping area, Tarim Basin, NW China.

\section{Geological setting}

The Keping section is situated along the southern part of Keping Uplift, northwestern flank of Tarim Basin, in the north of Keping County, southern Xinjiang, NW China (Figure 1). During the Early Paleozoic, the study area was located on a stable shallow marine carbonate platform on which very thick carbonate sediments up to $2000 \mathrm{~m}$ were deposited [15-17]. In the early Late Ordovician, carbonate deposition was terminated and gradually transferred into deepwater fine-grained siliciclastic deposition due to progressive transgression [18].

During the Early Permian, intense volcanic activities took place extensively in Tarim block as a result of convergent subduction of Middle Tianshan arc to the north $[19,20]$. Near the end of Permian, the further amalgamation led to an extensive uplift and subsequent long-term subaerial exposure and erosion of Tarim block. As a result, the Mesozoic sequences were mostly absent or missed along the north- western flank of the basin although locally present [21,22]. Since the Cenozoic, higher positive relief along the northwestern flank was reinforced due to the collision of Indian plate farther south and Asian plate, forming a series of NEE-striking, imbricated overthrust nappes, including the Keping Uplift along the northwestern flank of Tarim block $[20,23]$. On the contrary, the vast areas of plate interior were subject to an accelerating subsidence and plunged downwards to depths, forming the widespread negative relief of Tarim Basin surrounded by numerous uplifts (or mountains) as seen today [20,24].

\section{Methods}

Detailed outcrop investigations, descriptions and sampling upon the selected section at Keping County were firstly carried out. Then, detailed petrographic examinations were conducted on hand specimens and double-polished thin sections with thickened rock slices $(0.5-0.8 \mathrm{~mm})$ under microscope. These thin sections were further examined under the CL microscope to check the growth zonation on a RELIOTRON III stage from RELION Industries with a 5-8 $\mathrm{kV}$ beam and a gun current intensity of about 300-500 $\mu \mathrm{A}$.

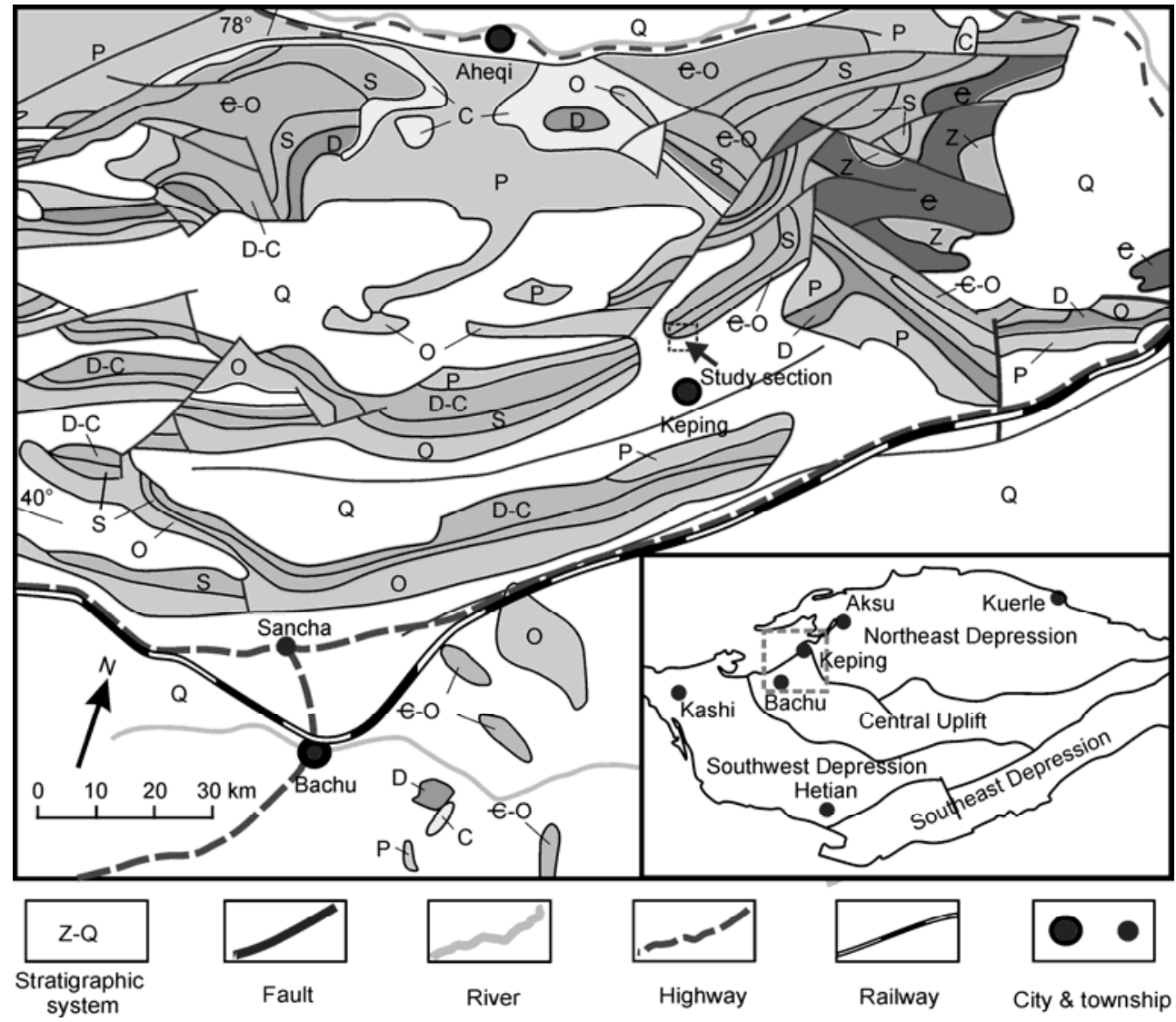

Figure 1 Simplified geological map in the Bachu and Keping counties, Tarim Basin, NW China. Inset map showing the main tectonic units in Tarim Basin Stratigraphic system: Z, Sinian (Neoproterozoic); C, Cambrian; O, Ordovician; S, Silurian; D, Devonian; C, Carboniferous; P, Permian; Q, Quaternary; Note the location of studied area (within the dashed square). 
When the well-developed growth zones are selected, the thin section was transferred to the stereomicroscope installed with micromill system and CL image was transmitted to the video mixing board and superposed on the aimed crystal. Afterwards, about 10-50 $\mu \mathrm{g}$ of saddle dolomite powers within CL-defined crystal growth zones were extracted under the microscope using a low speed micromill drill assembly. The drilled powders were collected on the micropipette tips that were held in place by suction from the vacuum pump [13].

Stable isotope analysis was performed with a Finnigan MAT-253 mass spectrometer equipped with a Kiel IV carbonate preparation device. The powders of each valve were reacted with $\sim 50 \mu \mathrm{L}$ of $103 \% \mathrm{H}_{3} \mathrm{PO}_{4}$ at $72{ }^{\circ} \mathrm{C}$ for $10 \mathrm{~min}$. The generated $\mathrm{CO}_{2}$-gases were measured for $\delta^{13} \mathrm{C}$ and $\delta^{18} \mathrm{O}$ values that are reported in per mille (\%o) relative to the $\mathrm{Vi}$ enna Peedee Belemnite (VPDB) standard. All the $\delta^{13} \mathrm{C}$ and $\delta^{18} \mathrm{O}$ values were normalized to NBS19. The precision is better than $0.15 \%$ or $\delta^{18} \mathrm{O}$ and $0.10 \%$ or $\delta^{13} \mathrm{C}$ [25].

In addition, Microthermometrical measurement of fluid inclusions was carried out using the double-polished thin sections. The analysis was performed on a Linkam THM600 heating-freezing stage that was calibrated using the Fluid synthetic standard. The accuracy of final melting tempera- ture of ice $\left(T_{\mathrm{m}}\right)$ and homogenization temperature $\left(T_{\mathrm{h}}\right)$ values is within 0.5 and $2.5^{\circ} \mathrm{C}$, respectively. All the analyses were carried out at the Institute of Geology and Geophysics, Chinese Academy of Sciences.

\section{Petrography of saddle dolomite cements}

In the studied section, the host dolostone is light to dark grey in hand specimen and consists of medium- to coarsely crystalline, non-planar tightly-packed matrix dolomites, ranging from $100 \mu \mathrm{m}$ to $2 \mathrm{~mm}$. Saddle dolomite crystals mainly occur as cements in the porous strata within a smallscale fault zone in the Lower Qiulitag Group of Upper Cambrian (Figure 2(a)). Within the fault zone, the dolostones were commonly subject to more intense fracturing and brecciation (Figure 2(b)), so that many fractures/ fissures and voids/cavities were produced. They were partially or completely filled by the saddle dolomite crystals and later calcite crystals (Figure 2(c) and (d)).

The saddle dolomite cements appear as milky white or pink in hand specimen, ranging from $250 \mu \mathrm{m}$ up to $4 \mathrm{~mm}$ in size, with scimitar-, or half-moon-like terminations, and extensively occur around breccias, and along the walls of
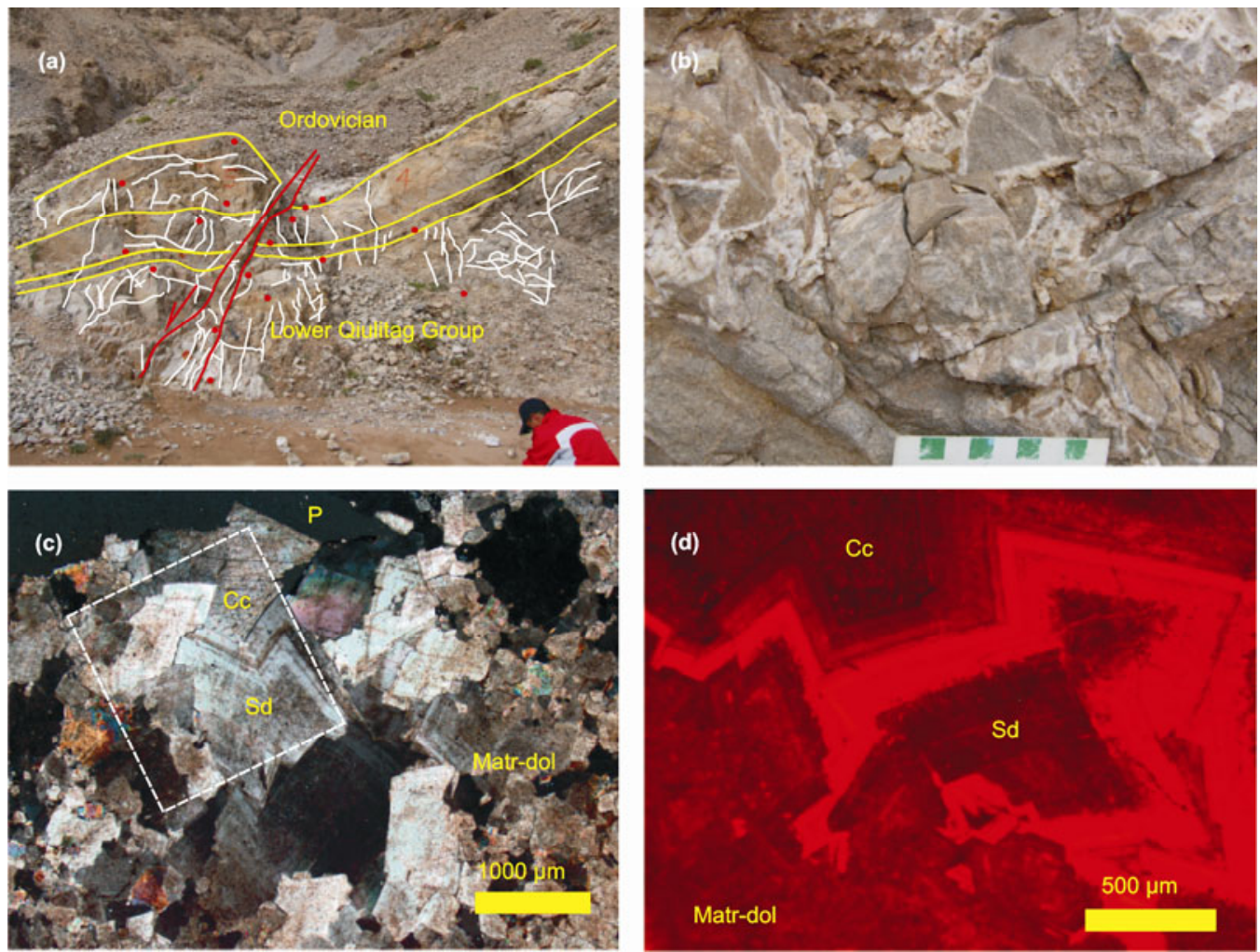

Figure 2 (a) Field photo showing the panoramic view of studied section near Keping County, NW Tarim Basin. Note the fault crosscuts the thick dolostone which is overlain by Lower Ordovician limestones. The white lines represent fractures/fissures. (b) Field photo showing intense brecciation of host dolostones along the fault. Note the fractures were nearly completely occluded by the milky white saddle dolomite cements. Scale in centimeter. (c) Photomicrograph showing saddle dolomite cement with different growth zones lining the wall of fracture. The inset dashed box is the area of (d). Cc, calcite cement; Sd, saddle dolomite cement; Matr-dol, matrix dolomite; P, relict porosity. cross-polarized light. (d) Photomicrograph of saddle dolomite cements under CL. Note the nonluminescent core, bright red inner zone and dull red outer zones. 
fractures and/or vugs (Figure 2(b)). They commonly exhibit curved or lobate crystal shape and display undulose extinction under cross-polarized light (Figure 2(c)). Under cathodoluminescence microscope, most saddle dolomite crystals display a broad non-luminescencent or dark red core surrounded by a thin bright red rim which is further followed by a non-luminescent or dull red zone in some crystals (Figure 2(d)). Therefore, the saddle dolomite crystals were formed through three generations (core, inner and outer zones) of growth.

\section{Results and discussion}

The $\delta^{18} \mathrm{O}$ and $\delta^{13} \mathrm{C}$ values of different growth zones within saddle dolomite crystals vary from $-13.8 \%$ to $-8.3 \%$ o VPDB and from $-1.5 \%$ to $-0.7 \%$ VPDB, respectively (Table 1). Of these, a large decrease in $\delta^{18} \mathrm{O}$ value by $3 \%$ to $5 \%$ is well revealed in the inner zones with respect to the cores to outer zones of crystals. By contrast, the $\delta^{13} \mathrm{C}$ values are less variable from crystal cores to the outer rims, alt- hough they are slightly low in inner zones as well (Table 1; Figure 3(a)).

The large fluctuations of $\delta^{18} \mathrm{O}$ values among growth zones of saddle dolomite crystals (Figure 3(a)) suggest episodic variations in temperature and/or composition of dolomitizing fluids during their precipitation. In this case, the cores and outer zones could have precipitated in dolomitizing fluids with a relatively low temperature, and the inner growth zones with the highest temperature. Microthermometry of fluid inclusions corroborates the temperature variations in dolomitizing fluids when corresponding zones formed, as is relatively low $\left(T_{\mathrm{h}}: 110\right.$ to $\left.130^{\circ} \mathrm{C}\right)$ in the cores and outer rims, the highest $\left(T_{\mathrm{h}}: 140\right.$ to $\left.170^{\circ} \mathrm{C}\right)$ in inner zones (Table 2; Figure 3(b)). This scenario indicates the oxygen isotope fractionation was mainly controlled by temperature in view of the persistently high salinity of dolomitizing fluids (Table 2). These data further suggest that the saddle dolomites were formed from high-temperature (or hydrothermal) dolomitizing fluids in which the kinetic barrier for dolomite formation was removed. Under this condition, the magnesium saturation became the key factor controlling
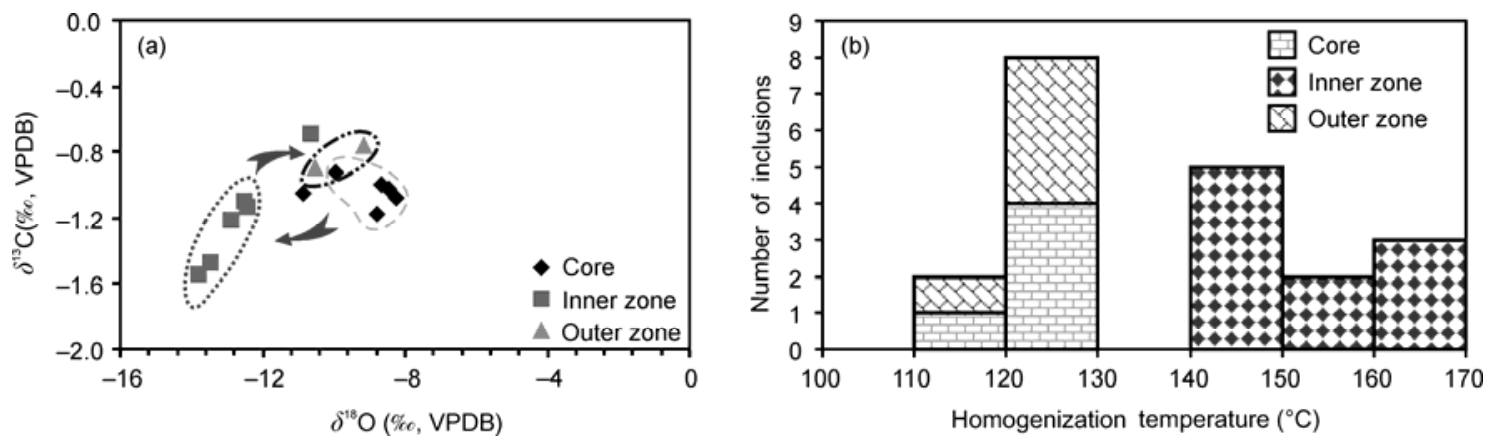

Figure 3 (a) Cross-plot of $\delta^{18} \mathrm{O}$ and $\delta^{13} \mathrm{C}$ values in different growth zones of individual dolomite crystals. Note the apparent isotopic offsets in the inner zone. (b) Histogram showing variations in homogenization temperatures $\left(T_{\mathrm{h}}\right)$ of fluid inclusions in different growth zones of saddle dolomites.

Table 1 In situ oxygen and carbon isotopic data of different growth zones of saddle dolomites and matrix dolomites at studied section

\begin{tabular}{|c|c|c|c|}
\hline Sample & Dolomite type & $\delta^{13} \mathrm{C}(\% \circ, \mathrm{VPDB})$ & $\delta^{18} \mathrm{O}(\% \circ, \mathrm{VPDB})$ \\
\hline 09kp-04-03 & core, non-luminescent band & -1.0 & -8.7 \\
\hline 09kp-04-04 & core, non-luminescent band & -1.2 & -8.8 \\
\hline 09kp-08-02 & core, non-luminescent band & -1.1 & -10.9 \\
\hline 09kp-08-05 & core, non-luminescent band & -1.1 & -8.3 \\
\hline 09kp-09-03 & core, non-luminescent band & -0.9 & -9.9 \\
\hline 09kp-04-03 & inner zone, bright red band & -1.5 & -13.8 \\
\hline 09kp-04-04 & inner zone, bright red band & -1.5 & -13.5 \\
\hline 09kp-08-01 & inner zone, bright red band & -1.1 & -12.5 \\
\hline 09kp-08-02 & inner zone, bright red band & -0.7 & -10.6 \\
\hline 09kp-08-05 & inner zone, bright red band & -1.1 & -12.4 \\
\hline 09kp-09-03 & inner zone, bright red band & -1.2 & -12.9 \\
\hline 09kp-08-05 & outer zone, faint dull red band & -0.9 & -10.5 \\
\hline $09 \mathrm{kp}-04$ & matrix dolomite & -1.1 & -8.0 \\
\hline 09kp-08 & matrix dolomite & -0.6 & -8.1 \\
\hline
\end{tabular}


Table 2 Fluid inclusion data of different growth zones of saddle dolomite cements at Keping County

\begin{tabular}{|c|c|c|c|c|c|c|c|c|c|c|c|}
\hline \multirow{2}{*}{ Sample } & \multirow{2}{*}{ Mineral type } & \multirow{2}{*}{$\begin{array}{c}\text { No. of } \\
\text { inclusions }\end{array}$} & \multicolumn{3}{|c|}{$T_{\mathrm{h}}\left({ }^{\circ} \mathrm{C}\right)$} & \multicolumn{3}{|c|}{$T_{\mathrm{m}}\left({ }^{\circ} \mathrm{C}\right)$} & \multicolumn{3}{|c|}{ Salinity (wt\% $\mathrm{NaCl}$ eq.) } \\
\hline & & & Min & Max & Mean & Min & Max & Mean & Min & $\operatorname{Max}$ & Mean \\
\hline $09 \mathrm{kp}-04$ & sd-crystal core & 4 & 106.2 & 147.9 & 120.2 & -23.0 & -13.0 & -16.8 & 16.9 & 24.3 & 19.8 \\
\hline 09kp-11 & sd-crystal core & 6 & 113.3 & 119.7 & 117.2 & -24.0 & -19.2 & -22.2 & 21.8 & 25.0 & 23.8 \\
\hline \multirow[t]{3}{*}{$09 \mathrm{kp}-11$} & sd-crystal core & 5 & 111.8 & 129.8 & 123.4 & -24.7 & -17.0 & -19.7 & 20.2 & 25.4 & 22.1 \\
\hline & sd-inner zone & 10 & 147.1 & 165.4 & 154.2 & -25.0 & -10.2 & -19.8 & 14.1 & 25.6 & 21.8 \\
\hline & sd-outer zone & 5 & 116.8 & 126.6 & 121.8 & -22.9 & -18.1 & -21.2 & 21.0 & 24.3 & 23.1 \\
\hline
\end{tabular}

dolomite precipitation [26,27]. On the other hand, the small variations of $\delta^{13} \mathrm{C}$ values among different growth zones (Figure 3(a)) suggest that the dolomitizing fluids were derived from similar carbon source in absence of organic input during dolomite precipitation. However, the lighter $\delta^{13} \mathrm{C}$ values in the inner zones may have contributed by more mantle-originated hydrothermal fluids, which could have provided more isotopically light carbon input.

The occurrence of saddle dolomites in the fault zone as cements or infills of fractures and associated vugs (Figure 2) indicates that their precipitation was structurally controlled. Under this condition, the fracture network system could have provided favourable conduits through which the deep-seated hydrothermal fluids from the underlying strata were readily channelled and migrated upwards. Regional stratigraphic data indicate there are thick dolostones (several 100s' to $\sim 1000 \mathrm{~m}$ thick) lie below the studied interval $[18,21]$. As the fluids migrated along the conduits that penetrated these dolostones, their magnesium content would increase and reach a level supersaturated with dolomite through progressive hydrothermal fluid dissolution of the host dolostones. The relatively consistent $\delta^{13} \mathrm{C}$ values that are similar to those of host dolostones (Table 1) are likely a reflection of such a scenario (Figure 4). The tectonic evolution of Keping Uplift suggests that it was subject to a significant elevation and possibly an exhumation in Mesozoic $[21,22]$, as evidenced by widespread absence of Mesozoic sediments (Figure 1). Therefore, the structurally controlled hydrothermal activity must have occurred prior to extensive exhumation, which was likely associated with the widespread intense magmatism in Tarim block in the Early Permian [19,20,28-30]. Under this circumstance, the regional magmatic activity could have reinforced rock fracturing, thermal diffusion and hydrothermal fluids migration into the more porous dolostones during magmatic emplacement. If so, the temperature fluctuations during dolomite precipitation as stated above may be a reflection of the evolution of magmatism, that is, relatively low at the start, the highest at

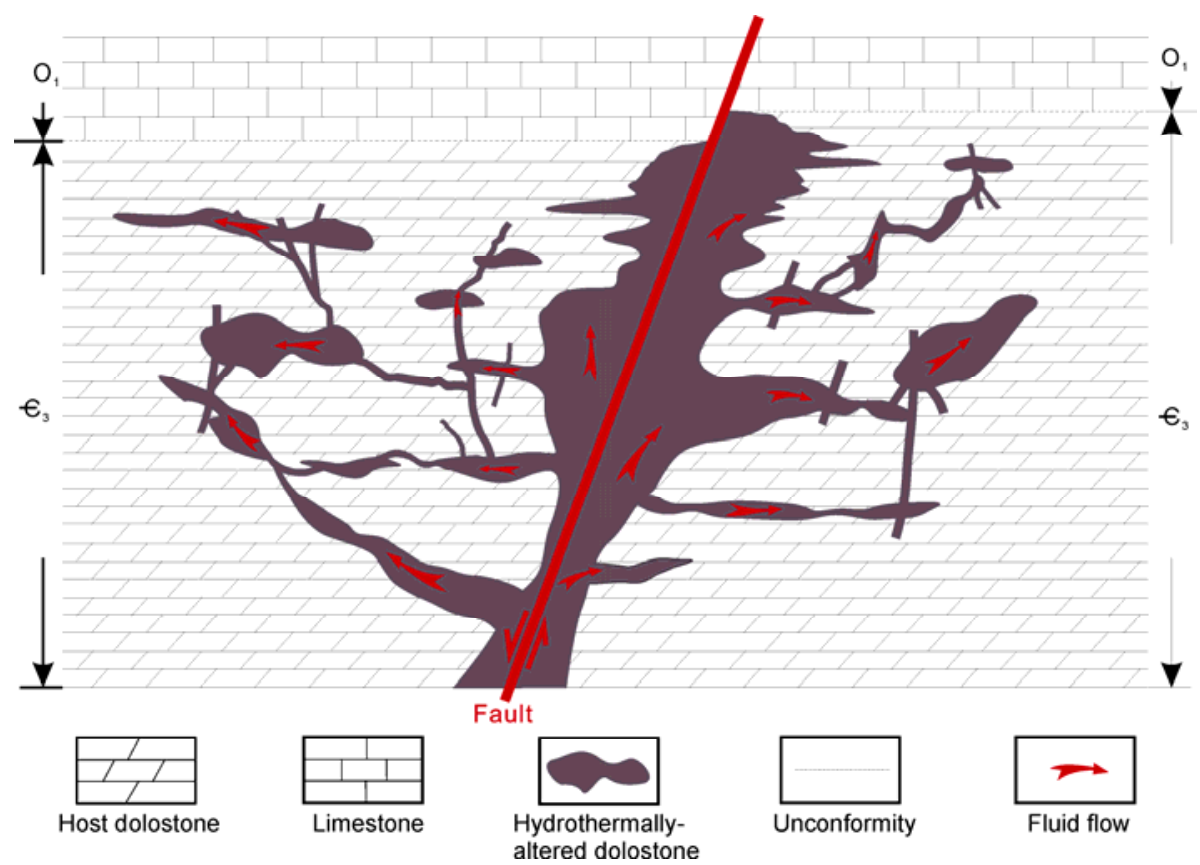

Figure 4 Conceptual model showing the structurally controlled hydrothermal dolomitization in the Upper Cambrian dolostones at studied section. The network fracture system could have worked as the principal conduits. Along these, the deeply-derived fluids were channelled and migrated upward and laterally into the host dolostones, resulting in hydrothermal alteration (or recrystallization) of the antecedent matrix dolomites and precipitation of saddle dolomites from the hydrothermal fluids in fractures and/or cavities. 
the acme and subsequent decrease at the waning stage of magmatism.

\section{Conclusions}

Saddle dolomites are commonly considered to be formed from hydrothermal fluids. This study used micromill sampling method, integrated with cathodoluminescence microscopy and fluid inclusion microthermometry, to conduct in situ $\delta^{18} \mathrm{O}$ and $\delta^{13} \mathrm{C}$ analysis for the growth zones of saddle dolomite crystals from the structurally-controlled dolostones in the Upper Cambrian, Keping, Tarim Basin. These data demonstrate large $\delta^{18} \mathrm{O}$ fluctuations in the intracrystal growth zones of saddle dolomites. Saddle dolomites precipitated in a heterothermal dolomitizing fluid probably linked to the different stages of magmatism emplacement within Tarim Block during the Permian. This study provides more accurate information of dolomitizing fluids and their evolution, and improves our understanding for the mechanism of dolomitization.

Lab work was assisted with Wang $X u$ (in situ $O$ and $C$ isotope analysis) and $\mathrm{Hu}$ Fangfang (fluid inclusion microthermometry) from Institute of Geology and Geophysics, CAS. We thank two referees and the editor for their constructive comments which substantially improved the manuscript. This work was supported by SINOPEC (G5800-07-ZS-WX032), the National Key Scientific Special Program of China (2008ZX05008-003-002 and 2011ZX05008-003-10), the National Basic Research Program of China (2012CB214802), the State Key Laboratory of Oil/Gas Reservoir Geology and Exploitation at CDUT (PL200801).

1 Machel H G. Fluid flow direction during dolomite formation as deduced from trace element trends. In: Shukla V, Baker P A, eds. Sedimentology and Geochemistry of Dolostones. SEPM Spec Publ, 1988, 115-125

2 Wilson E N, Hardie L A, Phillips O M. Dolomitization front geometry, fluid flow patterns, and the origin of massive dolomite: The Triassic Latemar buildup, northern Italy. Am J Sci, 1990, 290: 741-796

3 Qing H R, Mountjoy E W. Large-scale fluid flow in the Middle Devonian Presqu'ile Barrier, Western Canada Sedimentary Basin. Geology, 1992, 20: 903-906

4 Qing H R, Mountjoy E W. Formation of coarsely crystalline, hydrothermal dolomite reservoirs in the Presqu'ile Barrier, Western Canada Sedimentary Basin. AAPG Bull, 1994, 78: 55-77

5 Hitzman M, Allan J, Beaty D. Regional dolomitization of the Waulsortian limestone in southeastern Ireland: Evidence of large-scale fluid flow driven by the Hercynian orogeny. Geology, 1998, 26: 547-550

6 Machel H G, Cavell P A. Low-flux, tectonically-induced squeegee fluid flow ("hot flash") into the Rocky Mountain Foreland Basin. Bull Can Petrol Geol, 1999, 47: 510-533

7 Buschkuehle B E, Machel H G. Diagenesis and paleofluid flow in the Devonian Southesk-Cairn carbonate complex in Alberta, Canada. Mar Petrol Geol, 2002, 19: 219-227

8 Huang S J, Qing H R, Pei C R, et al. Strontium concentration, isotope composition and dolomitization fluids, in the Feixianguan Formation of Triassic, Eastern Sichuan of China (in Chinese). Acta Petrol Sin, 2006, 22: 2123-2132
9 Smalley P C, Stijfhoorn D E, Råheim A, et al. The laser microprobe and its application to the study of $\mathrm{C}$ and $\mathrm{O}$ isotopes in calcite and aragonite. Sed Geol, 1989, 65: 211-221

10 Sharp Z. In situ laser microprobe techniques for stable isotope analysis. Chem Geol, 1992, 101: 3-19

11 Sharp Z D, Cerling T E. A laser GC-IRMS technique for in situ stable isotope analyses of carbonates and phosphates. Geochem Cosmochim Acta, 1996, 60: 2909-2916

12 Wurster C M, Patterson W P, Cheatham M M. Advances in micromilling techniques: a new apparatus for acquiring high-resolution oxygen and carbon stable isotope values and major/minor elemental ratios from accretionary carbonate. Comput Geosci, 1999, 25: 1159-1166

13 Fouke B W, Rakovan J. An integrated cathodoluminescence videocapture microsampling system. J Sed Res, 2001, 71: 509-513

14 Spötl C, Mattey D. Stable isotope microsampling of speleothems for palaeoenvironmental studies: A comparison of microdrill, micromill and laser ablation techniques. Chem Geol, 2006, 235: 48-58

$15 \mathrm{Gu} \mathrm{J}$ Y. Characteristics and origin analysis of dolomite in Lower Ordovician of Tarim Basin (in Chinese). Xinjiang Petrol Geol, 2000, 21: $120-122$

16 Cai C F, Hu W S, Worden R H. Thermochemical sulphate reduction in Cambro-Ordovician carbonates in Central Tarim. Mar Petrol Geol, 2001, 18: 729-741

17 Zheng H R, Wu M B, Wu X W, et al. Oil-gas exploration prospect of dolomite reservoir in the Lower Paleozoic of Tarim Basin (in Chinese). Acta Petrol Sin, 2007, 28: 1-8

18 Zhou Z Y, Zhao Z X, Hu Z X, et al. Stratigraphy of the Tarim Basin (in Chinese). Beijing: Science Press, 2001. 1-359

19 Chen H L, Yang S F, Dong C W, et al. Confirmation of Permian basite zone in Tarim Basin and its tectonic significance (in Chinese). Geochimica, 1997, 126: 77-87

20 Tang L J, Zhang Y W, Jin Z J, et al. Opening-closing cycles of the Tarim and Qaidam basins, northwestern China (in Chinese). Geol Bull Chin, 2004, 23: 254-260

21 Jia C Z. Tectonic Characteristics and Petroleum, Tarim Basin, China (in Chinese). Beijing: Petroleum Industry Press, 1997. 1-295

22 Qu G S, Li Y G, Chen J, et al. Geometry, kinematics and tectonic evolution of Kepingtage thrust system (in Chinese). Earth Sci Front, 2003, 10: 142-152

23 Song F M, Min W, Han Z J, et al. Cenozoic deformation and propagation of the Kalpintag fold nappe (in Chinese). Seismol Geol, 2006, 28: 224-233

24 Shu L S, Guo Z J, Zhu W B, et al. Post-collision tectonism and basinrange evolution in the Tianshan belt (in Chinese). Geol J Chin Univ, 2004, 10: 393-404

25 Zhai D Y, Xiao J L, Zhou L, et al. Holocene East Asian monsoon variation inferred from species assemblage and shell chemistry of the ostracodes from Hulun Lake, Inner Mongolia. Quatern Res, 2011, 75: $512-522$

26 Warren J. Dolomite: Occurrence, evolution and economically important associations. Earth-Sci Rev, 2000, 52: 1-81

27 Carmichael S K, Ferry J M, McDonough W F. Formation of replacement dolomite in the Latemar carbonate buildup, Dolomites, Northern Italy: Part 1. Field relations, mineralogy, and geochemistry. Am J Sci, 2008, 308: 851-884

28 Yang S F, Li Z L, Chen H L, et al. Permian bimodal dyke of Tarim Basin, NW China: Geochemical characteristics and tectonic implications. Gondwana Res, 2007, 12: 113-120

29 Tian W, Campbell I H, Allen C M, et al. The Tarim picrite-basaltrhyolite suite, a Permian flood basalt from northwest China with contrasting rhyolites produced by fractional crystallization and anatexis. Contrib Mineral Petrol, 2010, 160: 407-425

30 Zhang C L, Xu Y G, Li Z X, et al. Diverse Permian magmatism in the Tarim Block, NW China: Genetically linked to the Permian Tarim mantle plume? Lithos, 2010, 119: 537-552

Open Access This article is distributed under the terms of the Creative Commons Attribution License which permits any use, distribution, and reproduction in any medium, provided the original author(s) and source are credited. 